\title{
Ties that bind and blur: financialization and the evolution of sovereign debt as private contract
}

\author{
Giselle Datz ${ }^{1}$ (1)
}

Received: 21 January 2021 / Accepted: 12 October 2021 / Published online: 26 October 2021 (c) European Association for Evolutionary Political Economy 2021

\begin{abstract}
The rich scholarship on the politics and finance of sovereign debt tends to take for granted debt's most basic form: as a private contract. Nevertheless, legal challenges have been central to the contemporary evolution of sovereign debt dynamics thanks to litigating strategies rendered possible by - mostly standard - contractual stipulations in international sovereign bonds. By using a debt-as-private-contract lens, the paper highlights how exposed sovereign debtors present themselves to these global transactions, how foreign sovereign bond contracts anchor otherwise footloose finance in particular jurisdictions, and how contractual changes sparked by outlier cases of protracted litigation or recent turbulence in debt exchanges have been key to global efforts to reform debt governance around market-based parameters. The legal battle between Argentina and its holdout creditors in US courts is analyzed here to illustrate these dynamics given its significance in sparking contractual revisions. Ultimately, it is clear that credit and contract are inextricably linked. Contractual evolution is revealing of the legal risks taken on by sovereign debtors and their creditors in private markets. The cost of debt hence may go beyond relatively predictable financial calculations.
\end{abstract}

Keywords Sovereign debt · Financialization - Law · Debt restructuring · Contract . Sovereign immunity

Sovereign debt never retires as an issue of ongoing concern for debtors, creditors, and the public at large. Yet there is no question that the COVID-19 pandemic has raised the stakes for upward trending debt dynamics in both developed and developing countries. Even prior to the onset of the pandemic, debt built up since 2010 was reported as "unprecedented in its size, speed and reach" (Kose et al 2020: 10). Since 2020, default rates have increased, and the need for debt restructuring has

Giselle Datz

gdatz@vt.edu

1 Government and International Affairs, School of Public and International Affairs, Virginia Tech, 900 N. Glebe Rd, office 06-010, Arlington, VA 22203, USA 
become more acute not only for low-income, but also for middle-income countries (Bulow et al. 2020). Given the ever-present threat of costly foreign litigation brought about by private creditors (known as holdouts) who refuse to accept an official debt restructuring offer put forth by the debtor, concerns about greater difficulties in creditor coordination have intensified yet again (IMF 2020).

Studies in International Political Economy (IPE) have advanced our understanding of the demand for sovereign bonds, as an explanatory variable to assess the impact of financial globalization on domestic policy autonomy and outcome. Deviating from the preferences of global investors for monetary stability and fiscal discipline could ignite capital outflows, increase the cost of credit, or both (Strange 1995; Mosley 2003; Brooks et al. 2015; Kaplan and Thomsson 2014). Yet there was more room to move with domestic politics in emerging markets than initially understood (Hardie 2006 and 2011, Rethel 2012), and even sovereign default was not an inhibitor of further interest in newly issued bonds (Datz 2009). More recent studies have revealed that sovereigns are not passive recipients of foreign credit. Rather, they deliberately tap into different sources of credit as a function of both domestic politics (Bünte 2019) and creditors' demands for information disclosure (Arias et al. 2020).

Shedding light onto supply (sovereign issuer) side considerations, new studies on the "financialization of the state" explain the strategic and (often) mutually advantageous ways in which debt management offices interact with market players, using private logics and significant discretion (Trampusch 2019, Karwowski and Centurion-Vicencio 2018, Fastenrath et al. 2017, Karwoski 2019, Livne and Yonay 2016, Datz 2008). "Financialized sovereign debt management," in particular, incorporates "market-based modes of governance" determined by financial economics rather than purely macroeconomics. Decisions regarding debt issuance derive from "optimization problems with cost-risk trade-offs" (Schwan et al. 2021: 823). In these significant contributions, sovereign debt issuance is more than a fiscal move; it is a financial transaction, revealing of the dynamic (rather than deterministic) constraints open economies face and work around in order to refinance debt and access new credit.

Neither demand nor supply side studies of sovereign debt pay close attention to the quintessential characteristic of sovereign bonds: these are essentially private contracts whose standardized legal stipulations dictate debtor-creditor interactions. Financialization is concerned with the production of "new credit lines drawn against the future" (Nevestailova and Palan 2020: 35-36), which become objects of speculation as financial assets. Since financial assets are "intangible capital that exists only in law," as contracts (Pistor 2019: 8), "much of modern finance depends on the relationship between financial institutions and the law." It is the latter which can render financial transactions more predictable thanks to the assurance of legal enforceability defined in private contracts (Carruthers 2020: 154). More broadly, contracts are where the tacit rules of capitalism are defined. Yet the ties they describe are far from static. As Pistor (2013: 2) explains, "law and finance are locked into a dynamic process in which the rules that establish the game are continuously challenged by new contractual devices, which in turn seek legal vindication." Bringing to fore the notion of debt as contract allows for an evolutionary understanding of the ways in which sovereigns present themselves 
to private credit markets, their (voluntary) exposure to foreign litigation, the learning curves there derived, and how these shape international bond contracts as tools of governance in the absence of a global bankruptcy court.

Bridging new studies on law and finance with studies on the political economy of sovereign debt and the financialization of the state, here it is argued that foreign sovereign bond contracts (i) instantiate sovereign debt disputes in particular locations, (ii) encapsulate the peculiarly market-based evolution of creditor-debtor relations in the absence of a global bankruptcy court for sovereigns, and (iii) code — in Pistor's (2019) sense - credit access in paradoxically well-defined and uncertain terms. "Well defined" because foreign sovereign bond contracts are usually "market standard" and sticky; they feature boilerplate clauses that rarely change (Gelpern et al. 2018; Choi and Gulati 2004). "Uncertain" because legal interpretations of contractual clauses can vary and enforcement, when made possible, can prove detrimental not only to sovereign debtors but the broader "financial plumbing system" (Verdier 2020). Together, these dynamics reveal that the cost of credit in terms of the (legal) risks assumed by the debtor go beyond predictable financial calculations.

Illustrating these points, here we embark on an empirical analysis of the legal battle between a hedge fund (NML) and Argentina in US courts. This is a crucial case in contemporary sovereignty debt analyses. It brought to light shortcomings in sovereign debt governance, set a judicial precedent for a new interpretation of a standard clause in bond contracts, and added legal ammunition to the arsenal of creditors' demands. Moreover, recent changes to foreign bond contracts (discussed in detail below) were triggered by the Argentine ordeal and motivated by the attempt to prevent such a disruptive outcome to debt restructuring processes.

The present study attempts to contribute to the literature on the financialization of debt by exposing the legal commitments that underpin foreign sovereign bonds, but by also by revealing a seldom-acknowledged parallel between the financialization of debt and the contemporary evolution of foreign sovereign bond contracts. In both cases, market strategies and devices inform debt issuance and - as highlighted here - the evolution of sovereign debt governance, marked by some multilateral (public) coordination around privately-set rules.

The first section of the paper links financialization and the law in the peculiar case of private contracts "signed" by sovereigns. Section 2 discusses one implication of these contractual stipulations, namely the importance of place for otherwise footloose finance, as illustrated by the Argentina debt litigation saga. Also following the implications of this case, Sect. 3 summarizes the evolution of foreign sovereign bond contracts since the early 2000s. The paper concludes reflecting on the importance of contracts for understanding the real and diverse costs of credit even if contractual changes to foreign sovereign bonds, on their own, are bound to remain an imperfect tool of debt governance. 


\section{Financialization and the law: the case of sovereign debt}

Financialization has been defined as the increasingly predominant role of financial incentives, strategies, logics, and tools in the global capitalism (Epstein 2005; Davis and Kim 2015). It is "both an economy-wide shift" and the "conjunctural application of specific financial values and technologies" to global economic production (Nesvetailova 2012: 68). The outcome is not only credit expansion, but "a profound change in the very processes by which credit is issued and distributed in the financial and economic system" (Wansleben 2020: 187-88).

Moreover, financialization is neither entirely novel nor a purely private sector phenomenon. As Flandreau et al. (2009:1) remark, this "emergence of global finance [associated with the 1990s financial globalization] was really a re-emergence." By 1900, "the use of modern communications to transmit prices; the development of a very broad array of private debt and equity instruments, and the widening scope for insurance activities; the expanding role of government bond markets internationally; and the more widespread use of forward and futures contracts, and derivative securities" spread to and linked major economic financial centers from Europe to the Americas, Asia, and Africa. Nonetheless, the evolution of international capital markets has not been linear. Rather, not only has broader financial integration been interrupted by domestic political imperatives that led to protectionism and capital controls, but, beyond macroeconomic policy switches, the "microeconomics of financial globalization" has endured marked changes (Flandreau 2017; Obstfeld and Taylor 2003).

When it comes to foreign debt, "the way the business of originating and distributing foreign debt is organized" has gone through a "profound transformation" in the twentieth century (Flandreau 2017: 160). Before the interwar era, underwriters functioned as "gatekeepers of liquidity and certification agencies." While the less prestigious underwriters originated bonds most likely to default, more reputable intermediaries dealt with less risky bonds. In contrast, thanks to the rise of rating agencies who provide assessments of sovereign risk, today "defaults are randomly distributed across underwriters," who have "become aggressive competitors in a new Speculative Grade market" that did not exist in the past (Flandreau et al. 2009: 7). Then, the underwriting business was highly concentrated. It provided a number of services for which large fees were collected. Quality standards were high, and most bonds originated were akin to today's investment grade securities. Nowadays, the business has become less concentrated among a few firms that, given economies of scale, charge less for their services (independently of bond spreads). Quality standards have decreased, and there is very limited cooperation between the borrower and the underwriter (Flandreau et al. 2009: 11).

Moreover, as sovereigns became more reliant upon bond finance, debt management evolved into a more autonomous and specialized function in public bureaucracies. The financialization of sovereign debt management turned public debt into actively traded financial assets, backed by deep secondary markets and financial logics assimilated by state officials (Karwowski 2019: 1011). The clear 
imperative is still to reduce the cost of debt (i.e., the interest paid on these bonds) through auctions featuring competitive bidding by bond investors (Fastenrath et al. 2017: 276-277, Datz 2008, Karwowski and Centurion-Vicencio 2018).

Within this insightful literature on the financialization of the state, however, debt is a financial asset whose legal coding or contractual form is mostly taken for granted in the debt management process, remaining thus largely exogenous to its financial relevance. As all contracts, the foreign sovereign bond contract is a legally binding agreement between the parties involved on their rights and commitments. Its current design encapsulates the incremental evolutionary process initiated in the early 2000 s, which saw in contractual changes a substitute for a necessary, albeit (so far) politically untenable, global sovereign bankruptcy mechanism (Gelpern et al. 2015; Brooks 2019; Brooks and Helleiner 2017).

We turn next to the peculiar features of the foreign sovereign bond contract before tracking its contemporary evolution. Since it was the Argentine debt restructuring, following the country's 2001 default, which sparked a new consensus on contractual changes, the case is explored below.

\subsection{The international sovereign debt contract}

As Choi and Gulati (2004: 929) describe them, "sovereign bond contracts are a special breed of contract. The parties involved are among the most sophisticated in the world financial markets, the amounts involved are large (hundreds of millions of dollars, in any given issuance), there is an active secondary market, and there is no meaningful regulatory body that interferes with contracting practices." Absent a formal set of universality applicable bankruptcy procedures, sovereign debt can never be discharged, and sovereign bond contracts can supposedly last forever (Lineau 2014). No creditor can be forced to accept a restructuring deal that offers less than face value. Indeed, refusing to join a debt restructuring deal (i.e., holding out) is a strategy pursued by a minority of bondholders. Since the early 2000 s, this possibility and its often-uncertain outcomes have been a cause of concern for debtors, their lawyers, creditors who do accept debt exchanges, international financial institutions, private trade associations, the UN, and, prominent among other public agencies, the US Treasury (Krueger 2002, Guzman and Stiglitz 2016; Sobel 2016).

Sovereigns, in turn, are exceptional debtors, "uniquely vulnerable and ... uniquely protected" (Buchheit 2013: 107). Despite not having access to debtor protections akin to those provided by corporate bankruptcy laws, sovereigns have enjoyed some protection in the legal arena. Even if sovereign property held abroad can be subject to seizure through a court judgment in favor of the creditor, money judgments are almost unenforceable by courts since most sovereign assets are immune from legal execution, and debtor countries can hide their executable assets outside of countries were litigation takes place (Gelpern 2013). 


\section{Footloose finance and its contractual anchor}

Place was easily blurred in depictions of the late twentieth- and early twenty-firstcentury global finance except for the notable literature on global cities (Sassen 2001; Brenner 1998). These were accounts of deliberate or inadvertent convergence in market movements and policy reforms, all subject to potentially sudden and inescapable financial volatility. "Disciplining" portfolio investors were diverse and mimetic, tracking common indexes, benchmarks, and reproducing the actions of market leaders in a context of information asymmetry (Santiso 2003). Moreover, these private players operated much more swiftly than ever before, at times exaggerating "market adjustments" (despite or beyond fundamentals) and even contributing to "sudden stops" of capital flows because of financial contagion from currency crises (Calvo 1998, Kaminsky and Schmukler 2003). As part of this broader process, the financialization of sovereign debt responds to these global dynamics and, particularly, exogenous shocks. Yet these footloose dynamics are not all the story in debt markets. When debt restructuring becomes the name of the game, private and public players are reminded of contractual commitments. Place then becomes not only explicit (as defined by the law governing the debt contract), but inescapable, a site of legal accountability with extraterritorial tentacles.

In particular, for sovereign debtors, place is pertinent when it comes to debt issuance and decisions about currency denomination, choice of law, and stock market listings (de Fonteney et al. 2016). Developing countries often borrow in foreign currency even though exchange rate depreciations make it more difficult for them to service their debts (Eichengreen et al. 2003). For those who can issue both local and foreign-currency denominated bonds, the first are seen as riskier by investors and hence more costly for the debtor (Bradley et al. 2018; Chamon et al. 2018). A similar calculation leads sovereigns to issue bonds governed by foreign law, almost always submitting to courts in the designated jurisdiction. Issuing bonds in foreign currency and subject to foreign law means that emerging market countries can generally take advantage of lower interest rates than those charged for domestic-law, domestic-currency bonds (Weidemaier and Gulati 2016, Buchheit 2013, Olivares-Caminal 2013). Because creditors seem to believe that "foreign courts will more rigorously enforce sovereign debt obligations," a substantial portion of emerging market sovereign bonds is governed by New York or English law (Weidemaier and Gulati 2017: 9, Das et al. 2012).

Contemporary dynamics involving litigation against sovereigns are informed by the 1976 passage of the Foreign Sovereign Immunities Act (FSIA) in the USA and the State Immunity Act of 1978 (SIA) in the UK. These are the key legislative references in the transition from "absolute" to "restrictive" immunity. No longer are sovereigns "presumptively immune from suit even when engag[ing] in commercial activity abroad." In fact, while before 1976 virtually no bond contained a waiver of immunity from suit, since then all foreign issued sovereign bonds waived this immunity" (Weidemaier and Gulati 2017: 7, Weidemaier 2014). Although courts "were reluctant to enforce privately-negotiated immunity 
waivers until relatively late in the twentieth century," the tables have turned more recently (Weidemaier and Gulati 2016: 34), when "specialized distressed debt funds - expert litigators - [with] the patience, skill and deep pockets to exploit the loopholes of sovereign immunity" successfully sued sovereign debtors in international courts (Committee on International Economic Policy and Reform 2013:16). This minority of creditors often operate with the intent of disrupting debt deals as a part of their profit-seeking calculus. Their actions are not only authorized by law, but a contractually-based form of "sabotage" (Nevestailova and Palan 2020).

As a result, sovereign debtors approach international bond markets voluntarily exposed to the potentially high costs of foreign litigation. No case has made these costs clearer than the Argentine battle with holdout creditors in US courts from 2001 to 2016. We turn next to a brief review of the case's main developments and outcomes.

\subsection{NML vs. the Republic of Argentina}

Rejecting both the 2005 and 2010 exchange offers presented to creditors for bonds defaulted in 2001, NML Capital (a hedge fund subsidiary of Elliott) pursued payment in US courts. In the September 2011 hearing for the Southern District of New York (SDNY), the lawyers for Argentina argued that the Foreign Sovereign Immunities Act protected its bond payment actions. Contradicting that view, in December 2011, New York District Court Judge Griesa ruled in favor of NML. For him, Argentina violated a standard (boilerplate) clause in sovereign bond contracts: the pari passu clause (implying "equal treatment" among creditors). ${ }^{1}$ This happened when the country continued paying bondholders of restructured bonds while refusing to pay holdout creditors. With this unusual interpretation, Judge Griesa read the pari passu clause as forbidding Argentina from paying its other creditors unless it also paid NML "proportionally"2 (Gelpern 2013; Cotterill 2013).

Expecting Argentina to defy his orders, in 2021, judge Griesa issued an injunction (i.e., a restraining judicial order) prohibiting the country from paying its restructured debt unless it paid NML in full ${ }^{3}$ (Gelpern 2013). Crucially, the injunctive order threatened to sanction financial third parties working with Argentina so they would not make possible the country's repayment of exchange bondholders without payment to NML as well. In fact, the amended injunction of 2012 cited each

\footnotetext{
1 The pari passu clause, a common addition to sovereign debt contracts, was stipulated in Argentina's original 1994 debt contract as a promise to treat all payment obligations as equal "in ranking with other unsecured external" debt commitments of the country (Gelpern 2013: 3).

2 The Argentine Congress passed a law, he Padlock Law (or, locally, ley cerrojo) in February 2005 prohibiting the Executive from reopening the exchange without the holdout creditors (Clarín 2012). This law supported judge Griesa's reading of subordination of one creditor to another, which undermined the key premise in the pari passu clause.

3 Injunctions are perceived as a "remedy" that should be granted when a plaintiff has no other option and only if the "remedy" is consistent with the equitable exercise of a court's power (Weidemaier and Gelpern 2013).
} 
of Argentina's financial intermediaries, making clear the extraterritorial ambition of the order. Among them were clearing houses (the Depository Trust Company, Clearstream Banking, Euroclear Bank, and the Euroclear System) and paying and transfer agents (The Bank of New York in Luxembourg and The Bank of New York Mellon in New York and London). ${ }^{4}$

The rationale for NY Judge Griesa's injunction was that extraterritorial scope was needed to force Argentina to comply - a point supported by the Court of Appeals, despite vehement opposition by foreign financial intermediaries (Weidemaier and Gelpern 2013: 34). For Euroclear's lawyers, the injunction expanded "the authority of the US courts beyond the borders of the US to activities carried out by governmental and other institutions in Europe" (Euroclear 2014: 8-9). To make matters worse, the injunctive order was "in direct conflict with Belgian law," which prohibited "attachment or blocking of (...) any cash transfer" given its detrimental effect on "the proper functioning of payment or settlement systems and hence to (...) the credibility and the liquidity of national and international financial markets" (10). Nevertheless, the order endured. Ultimately, it looked a financial sanction. It was not one leveled by a sovereign on defiant foreign powers, but one "imposed outside the political process by a judge acting at the behest of private parties in contractual dispute" (Verdier 2020:177). Strong-arming financial intermediaries meant that Argentina could not pay bondholders of the its 2005 and 2010 exchanged bonds when they came due in 2014. The country then entered in technical default.

After taking office in December, 2015, new President Macri and his team wasted no time in approaching holdout creditors, offering to pay $\$ 6.5$ billion in cash for claims of $\$ 9$ billion in February 2016 (Financial Times, 29 February, 2016). That meant paying the original principal on defaulted bonds plus $50 \%$. In total, the Argentine government paid USD 9.3 billion to holdout creditors, including Italian bondholders, NML Capital, and other hedge funds (Financial Times, February 29, 2016; La Nación, April 23, 2016).

Despite the conclusion of NML vs. the Republic of Argentina in US courts, the case lives on in debates over sovereign debt restructurings. It has motivated contractual changes and strengthened the hand of creditors in unpredictable sovereign debt games.

\section{Contractual changes in international sovereign debt bonds}

As the Argentine case illustrates, a single particularly controversial and consequential clause "in a defaulted bond contract, fifty-five pages long and twenty years old, led a nation of forty-one million people to default on \$29 billion in new debt" when it entered in technical default in 2014 due to an injunctive order issued by a NY district court judge (Gelpern et al. 2018: 3). Sovereign bond contracts had

\footnotetext{
${ }^{4}$ Order, NML Capital, Ltd. v. Republic of Argentina, No. 08-cv-6978 (S.D.N.Y. Feb. 23, 2012), Dkt. No. 371.
} 
been the object of enthusiastic attention in the sovereign debt arena particularly since 2003, when Mexico first issued collective action clauses (CACs) in its New York-law bonds ${ }^{5}$ (Gelpern 2016). The clauses allowed for a majority of bondholders to approve a restructuring, making it easier for the process to unfold without the stricter need for unanimity.

As a result of the 2013 deliberations by the "Sovereign Debt Roundtable" — an informal grouping of creditors, bankers, lawyers, and public officials led by US Treasury - contractual changes to international sovereign bonds were published by the London-based International Capital Market Association (ICMA) and backed by the IMF (Sobel 2016: 3, ICMA 2014, IMF 2014). ${ }^{6}$ These changes were not only directly motivated by the Argentine legal battle in US courts, but also by the Greek debt exchange of 2012. A key particularity of the latter was that the vast majority of "old" sovereign bonds (about 86\%) had been issue under Greek law and contained no CACs. That is to say, Greek-law bonds could only be restructured with the unanimous consent of bondholders. In order to avoid this hurdle, "the Greek legislature passed a law (....) allow[ing] the restructuring of the Greek law bonds with the consent of a qualified majority, based on a quorum of votes representing $50 \%$ of face value and a consent threshold of two-thirds of the face-value taking part in the vote. Importantly, this quorum and threshold applied across the totality of all $€ 177.3$ billion Greek law sovereign bonds outstanding, rather than bond-by-bond." What was achieved with this "retrofit CAC"? It rendered it "near impossible" for bondholders to block the restructuring (Zettlemeyer et al. 2012: 7).

The success of the 2012 exchange of Greek-law bonds notwithstanding restructuring English-law bonds (which did feature CACs) was a different matter. Of the 36 bond issuances governed by English law that were eligible to participate in the debt exchange, and which contained CACs, only 17 were successfully restructured using CACs. Holdout creditors managed to acquire blocking positions in the remaining bond issues, resulting in unrestructured claims of about $€ 6.4$ billion (approximately $30 \%$ of total foreign-law Greek debt) [IMF 2012; Zettlemeyer et al. 2012]. Greece chose to avoid litigation with holdout creditors and those where hence repaid (Reuters, May 15, 2012).

Despite setting a record for the "extensive use of collective action clauses," the Greek experience made clear "the difficulties with using bond-by-bond CACs in comprehensive restructuring attempts, where blocking minorities in one issue cannot be offset by pro-restructuring majorities elsewhere" (Zettlemeyer et al. 2012: 26). Enthusiasts of market-based contractual reform hence had reason to both place renewed faith in these clauses and push for more strategic modalities that would prevent the bond-by-bond blocking disruption unleashed by tenacious holdout creditors.

The Greek experience also made clear that contract changes serve not only to preemptively protect the debtor from legal dispute but can entice creditors in an

\footnotetext{
5 English-law bonds already featured these clauses.

6 The IMF, in its own words, supported and encouraged the "strengthening of the contractual framework" for international sovereign bonds. Yet it "cannot mandate the inclusion of [enhanced collective action] clauses (...), nor determine their design" (IMF 2014: 5).
} 
exchange. Zettlemeyer et al. (2012: 3) remark that 97\% of old Greek debt restructured in 2012 counted on two effective incentives: "an unusually high cash payout" of $15 \%$ of the value of the old bonds as well as contractual terms in the new bonds which gave them a "much better chance of surviving future Greek debt crises relatively unscathed than the old ones."

\subsection{Sticky bonds and (plain-vanilla) changes}

Given how much distress the pari passu clause - preventing the involuntary subordination of an existing creditor to other(s) - caused to sovereigns like Argentina, why not do away with it in new contracts? After all, as Buchheit and Martos (2014: 492) point out: "Never having had a clear idea of what purpose the pari passu clause actually served in a cross-border debt instrument, underwriters and most investors will surely not have a clear idea of the implications of not having it." Yet, relative inertia rules debt contracts, and it is deliberate. Interviews with debt managers and investors conducted by Gelpern et al. (2019: 620) revealed that they prefer standard form contracts (common in commercial deals) even where a "market standard" is not clearly or formally defined (Choi and Gulati 2006). The financialization of state debt, after all, imbues debt management with the imperative of selling debt at the lowest possible cost to the issuing government. Debt managers try to avoid the risk that any changes in contractual terms may negatively differentiate a sovereign in its cohort of issuers. Standardization implies "continuity of the debtor-creditor relationship and consensus on market practices" (Gelpern et al. 2019: 620).

In his insider's account of discussions about changes to the pari passu clause, Sobel (2016: 7) notes that while some members of the "Sovereign Debt Roundtable" (which inspired the ICMA standards proposal) supported the elimination of the clause from bond contracts, others were concerned about potentially detrimental market reaction. Hence they proposed retaining a rewritten version that disavowed the ratable payments interpretation of the clause, which had catalyzed Argentina's legal troubles. When it came to new aggregation rules to be incorporated in CACs, the goals were to "reduce the scope for obtaining blocking positions, provide the sovereign with greater flexibility and at the same time protect against possible abuse or oppression of the minority by sovereigns." The final proposal for an enhanced CAC contained "a menu of voting procedures, including a 'single-limb' aggregated voting procedure that enables bonds to be restructured on the basis of a single vote across all affected instruments, a two-limb aggregated voting procedure, and a series-by-series voting procedure" (IMF 2019: 3). This was critical because recent empirical work and derived simulations show that CACs are effective in "minimizing the holdout problem" when single-limb aggregate voting is specified. CACs with bond-by-bond voting, in contrast, are insufficient to assure high rates of creditor participation in restructurings (Fang et al. 2020).

As Gelpern et al. (2019: 629) put it: "the ink had barely dried on the IMF executive board's endorsement of ICMA CACs before adoptions began in countries as different as Kazakhstan, Vietnam, and Mexico." In fact, 88\% percent of all 510 international sovereign bond issuances since October 1, 2014 (totaling US\$ 620 billion) 
included the enhanced CACs that allow for a supermajority of creditors to determine the voting outcome on restructuring terms (IMF 2019). The decision to include enhanced CACs in their contracts did not increase the cost of credit for sovereign borrowers, according to recent empirical investigation by Chung and Papaioannou (2020). Creditors associate these clauses with a more efficient resolution of debt restructurings, rather than with moral hazard. ${ }^{7}$

Moreover, since September 2017, all issuances that have included the enhanced CACs also included modified pari passu provisions, with the exception of those issued by Bahrain, Indonesia, Pakistan, and Russia. Even sovereign debtors who did not include enhanced CACs in their newly issued bond contracts (Azerbaijan and Macedonia under English law, and Lebanon under New York law) did add reviewed pari passu clauses. EU sovereigns are an exception in this group. Yet, "while there have been variations in the formulation of the modified clauses, they all specifically disavow the obligation to make ratable payments" (IMF 2019: 6). No one wants to relive Argentina's court struggles.

\subsection{The 2014 enhanced CACs put to the test}

In August 2020, Argentina concluded a restructuring of US\$65 billion in debt in default (the country's nineth). A total of $99 \%$ of private creditors accepted the government's offer with its $50 \%$ haircut. The deal extended maturities and lowered interest rate payments from about 7 to 3\% (Financial Times, August 31, 2020). Like in the case of the Ecuadorian debt restructuring of September 2020, the two-limb aggregated voting mechanism (requiring a 75\% majority) in CACs was first used, helping to discourage holdout creditors. ${ }^{8}$ The "potentially more robust single-limb voting feature of enhanced CACs" has not been used yet (IMF 2020: 25). In both Ecuador and Argentina, a novel use of CACs was "to give less favorable financial terms to holdout creditors, providing an additional incentive to participate in the exchange." In fact, "non-consenting holders" of Argentine debt "were mandatorily exchanged for new bonds, which, in some cases, have the least favorable maturity structure and do not contain creditor protections in the event of a future, more favorable offering" (27).

While the Ecuadorian government was praised for its "transparent engagement strategy with creditors" (IMF 2020: 21), both this country and Argentina made clear that sovereign debtors were willing to "re-designate at any time-even after the exchange offer closed-which series of bonds would be aggregated together for voting purposes." That is, the Argentine government would manipulate the voting tally by taking those bond series that voted against the restructuring and place them in a different pool, guaranteeing hence its desired outcome (i.e., to go on with the offer it had made to all bondholders, claiming it counted on the consent of a majority

\footnotetext{
7 The study analyzes a sample of bonds issued from September 2014 to March 2020, hence leaving out the 2020 Argentine and Ecuadorian restructured bonds.

${ }^{8}$ Ecuadorian restructured debt had been issued under NY law. Argentine bonds followed NY and English governing laws (IMF 2020).
} 
of creditors). In addition, Argentina was said to restructure "a subset of bonds, and then sweeten the terms to try to convince an increasing proportion of creditors to play along. Each successive round snap[ed] up more approvals - a strategy nicknamed 'Pac Man,' which makes it more difficult for opposing bondholders to block a deal" (Financial Times, June 30, 2020). This frustrated - to put it mildly - not only creditors but also officials and lawyers who had been supportive of the ICMA CACs featured in the exchanged bonds (Sobel 2020; Gelpern 2020). For them, debtors were in effect "gerrymandering ideal voting pools to maximize the cram down of holdout creditors" and thus undermining the "fairness and integrity" of the restructuring process (IMF 2020: 25).

Ultimately, Argentine and Ecuadorian creditors entering the restructurings "negotiated specific refinements to the ICMA CACs [in the new bonds] to rectify the identified flaws and safeguard the spirit of the ICMA architecture" (IMF 2020). The governments of Argentina and Ecuador accepted the proposals (Clark and Lyratzakis 2021). These modifications notwithstanding, the experience illustrated the point legal scholars know better than most: "how hard it is-really, impossible-to draft bulletproof contracts" (Gulati and Weidemaier 2020).

\subsection{Contractual Chimera?}

It is hence no surprise that, despite talks of progress regarding the "sovereign debt architecture" thanks to CACs-related contractual changes, hardly any seasoned observer would express absolute contentment. These initiatives have been seen as second-best to the creation of a statutory debt restructuring mechanism, long discussed but still missing broad political backing. The USA, in particular, has opposed the IMF's proposed Sovereign Debt Restructuring Mechanism (SDRM) in 2003 and the UN General Assembly Resolution on Basic Principles on Debt Restructuring Processes alleging that a statutory approach to debt deals will increase market uncertainty with deleterious impact on sovereign bond markets. Yet the USA has not been alone is this opposition. Although most developing countries supported the 2014 UN General Assembly Resolution (by definition, non-binding), they also hesitated to back the IMF's proposed SDRM, given its potential to compromise market access (United Nations 2014; Setser 2008; Helleiner 2008).

The contractual change approach, favored by market actors, also reflected "the revealed preferences of Treasury Department officials during both the Clinton and Bush Administrations." A G-10 working group recruited a group of seasoned sovereign debt lawyers to draft CAC provisions for debt contracts under NY law. US Treasury officials encouraged emerging market sovereigns to incorporate these contractual changes (Tarullo 2004: 681, Setser 2008). They materialized in the 2003 Mexican bond issue and were quickly also embraced by other sovereign debtors issuing new bonds (Gelpern and Gulati 2013). By the end of that year, 70 to $80 \%$ of all new emerging markets sovereign debt issued in the New York had CACs (Bradley and Gulati 2012).

Yet there are many reasons why contracts alone will not do away with serious problems emerging from debt restructurings. First, even though international 
sovereign bonds that include enhanced CACs grew from $27 \%$ of the total outstanding stock as of end of September 2017 to 39\% as of end of October 2018, it will take some years for all existing bonds without enhanced clauses to mature. Of those, about $31 \%$ will mature in more than 10 years (50\% of which are "junk bonds"). Also, "close to $70 \%$ of the bonds maturing in more than 10 years are governed by New York law, and may pose risk of holdout behavior" (IMF 2019: 6).

Second, the contractual changes discussed here say nothing of official debt. IMF officials now openly argue that "official bilateral creditors should agree on a common approach to restructuring official bilateral debts" that involves Paris Club members "and others" - clearly, China whose contract terms are far from public knowledge (Gelpern 2018, Horn et al. 2020 Gelpern et al. 2021). Restructurings terms should be transparent and provide comparable terms to private and official creditors so as to increase participation and "avoid costly delays" (Georgieva et al. 2020). The G-20's 2020 Common Framework for Debt Treatments beyond the Debt Service Suspension Initiative (DSSI) ${ }^{9}$ indeed includes non-Paris Club official creditors and aims at promoting "comparability of treatments" for all creditors in each restructuring case (G-20 2020). Whether the Framework will spark needed commitments that make a difference for the possible new wave of "post"-pandemic restructuring is history in the making.

Third, "best practices" initiatives follow a common pattern in financial regulation. As Brummer (2010: 623) explains: "Unlike international trade and monetary affairs, where global coordination efforts are led by formal international organizations, international financial law is promulgated by inter-agency forums with (at best) ambiguous legal status." Contractual changes - not unlike such informal financial regulatory tactics - "provide a decisively cheaper means of agreementmaking," one with "fewer "sovereignty costs" or constraints that may limit the ability of a state to follow its own national prerogatives" (Brummer 2010: 631), whatever the binds that contracts impose, which are never definitive in practice.

\section{Conclusion}

A key part of the process of financialization of sovereign debt is the private contract defining the roles and rights of debtors and creditors. This is a tool of governance at the micro level, establishing who the sovereign is in this transaction (i.e., a commercial player), where legal enforcement can be petitioned, and which litigation strategies can be attempted to advance the cause of dissatisfied and/or opportunistic creditors. It is also a tool at the macro level since local judicial authority in cases of international debt litigation has no teeth without extraterritorial reach and, more specifically, the ability to hold financial intermediaries in contempt of a court order

\footnotetext{
${ }_{9}$ The G-20 DSSI authorized debt service suspension for 44 eligible countries who requested it. First granted for 6 months in 2020, it was extended through the end of June 2021 (World Bank 2020). The IMF and World Bank are advocating for a further extension which may come forth in the spring of 2021 (Malpass 2020).
} 
if its decision is not followed. Important discontinuities in the contemporary history of sovereign debt are defined by these dynamics, rendered possible by international debt contracts.

In particular, the pari passu and collective action clauses in international sovereign bond contracts have been featured prominently in court disputes experienced by outlier cases of protracted litigation. Yet, largely because of these outlier cases, the clauses have been the subject of concerted private and public attention in efforts towards contractual changes and clarifications, broadly embraced (Datz and Corcoran 2019). Therefore, the contract is both the key to explaining some of the most pressing concerns in the sovereign debt arena - such as the assessment of legal risk (potential costs) of sovereign bond finance - and an insufficient response to these problems. Contractual changes move the dial towards some uniformity that may preempt disruptive outcomes. Yet, as a tool of market-based governance in the absence of public/multilateral consensus, contracts do not eliminate uncertainty or inefficiency.

Future research on financialization can carry further the effort of identifying the legal premises underpinning market strategies emanating from both the public and private sectors in order to discern how relationships are "coded," tied together and paradoxically blurred given lawyers' daring strategies and (unpredicted) judicial interpretations. To be sure, in the sovereign debt arena, not only are foreign bond contracts to be taken into account when making sense of the risks to which debtors expose themselves when seeking credit abroad. Strides have been recently made toward accessing and dissecting bilateral deals between China and its developing countries debtors (Gelpern et al. 2021). In sovereign bonds as in commercial deals, credit and contract are inextricably linked. Contractual evolution has hence much to reveal about the real and diverse costs of sovereign credit. The host of political implications there derived is yet to be identified and explored by students of sovereign debt.

\section{References}

Arias E, Mosley L, Rosendorff P (2020) Financial statecraft: government choice of debt instruments. University of North Carolina, Manuscript

Bradley M, Gulati M (2012) Collective action clauses for the eurozone. Duke University - Fuqua Shool of Business and Duke University: manuscript.

Bradley M, de Fontenay E, de Lira Satuatierra IA, Gulati M (2018) Pricing sovereign debt: foreign vs. local parameters. European Financial Management, 24(2): 261-297.

Brenner N (1998) Global cities, glocal states: global city formation and state territorial restructuring in contemporary Europe. Review of International Political Economy 5(1):1-37

Brooks S (2019) The politics of regulatory design in the sovereign debt restructuring regime. Glob Gov 25(2019):393-417

Brooks Skylar, Helleiner Eric (2017) Debt politics as usual? Reforming the sovereign debt restructuring regime after 2008. International Affairs 93(5):1085-1105

Brooks S, Cunha R, Mosley L (2015) Categories, creditworthiness, and contagion: how investors' shortcuts affect sovereign debt. Int Stud Quart 59(3):587-601

Brummer C (2010) Why soft law dominates international finance-and not trade. J Int Econ Law 13(3):623-643 
Buccheit L, Martos S (2014) What to do about pari passu. Journal of Banking and International Finance (September): 491-493

Buchheit L (2013) Sovereign debt restructurings: the legal context”, BIS Papers, Basel, 8 January.

Bulow J, Reinhart C, Rogoff K, Trebesch C (2020) The debt pandemic. IMF Finance \& Development (September): $12-16$

Bünte J (2019) Raise the debt: how developing countries choose their creditors. Oxford University Press, New York

Calvo G (1998) Capital flows and capital-market crises: the simple economics of sudden stops. J Appl Econ 1:35-54

Carruthers B (2020) Law, governance, and finance: introduction to the theory and society special issue. Theory Soc 49:151-164

Chamon M, Schumacher J, Trebesch C (2018) Foreign-law bonds: can they reduce sovereign borrowing costs?. CEPR Discussion Paper No. DP13020

Choi S, Gulati M (2004) Innovation in boilerplate contracts: an empirical examination of sovereign bonds. Emory Law Journal 58:929-996

Choi S, Gulati M (2006) Contract as statute. Mich Law Rev 114(2006):1129-1173

Chung K, Papaioannou M (2020) Do enhanced collective action clauses affect sovereign borrowing costs?. IMF Working Paper No. 20/162

Clarín (2012) Ley Cerrojo: Una jugada que se volvió en contra. Buenos Aires, 26 October

Clark I, Lyratzakis D (2021) Towards a more robust sovereign debt restructuring architecture: innovations from Ecuador and Argentina. Capital Markets Law Journal 16(1):31-44

Committee on International Economic Policy and Reform, Institution B (2013) Revisiting sovereign bankruptcy. Brookings Institution, Washington, DC

Cotterill J (2013) Sovereign pari passu and the litigators of the lost cause. Capital Markets Law Journal 9(1):18-25

Das US, Papaioannou M, Trebesch C (2012) Sovereign debt restructurings 1950-2010: literature survey, data, and stylized facts. IMF Working Paper No. 12/203.

Datz G (2008) Governments as market players: state innovation in the global economy. J Int Aff 62(1):35-49

Datz G (2009) What life after default? Time horizons and the outcome of the Argentine debt restructuring deal. Review of International Political Economy 16(3):456-484

Datz G, Corcoran K (2019) Deviant debt: reputation, litigation and the outlier effects of Argentina's Debt restructuring saga. New Political Economy 25(2):300-313

Davis G, Kim S (2015) Financialization of the economy. Ann Rev Sociol 41:203-221

de Fonteney E, Meyer J, Gulati M (2016) The sovereign debt listing puzzle. Duke Law School Public Law \& Legal Theory Series No. 2017-4

Eichengreen B, Hausmann R, Panizza U (2003) The pain of original sin, in Barry Eichengreen and Ricardo Hausmann (eds.), Debt denomination and financial instability in emerging-market economies, Chicago: University of Chicago Press.

Epstein G (2005) Financialization and the World Economy. Edward Elgar, Cheltenham

Euroclear Bank SA (2014) Brief of Amicus Curiae Euroclear Bank SA/NV in support of petitioner, March 24. Available at: http://www.creditslips.org/files/euroclear-amicus-brief.pdf

Fang C, Schumacher J, Trebesch C (2020) Restructuring sovereign bonds: holdouts, haircuts and the effectiveness of CACs. European Central Bank Working Paper No. 2366.

Fastenrath F, Schwan M, Trampusch C (2017) "Where states and markets meet: the financialization of sovereign debt management. New Political Economy 22(3):273-293

Financial Times (2016) Argentina debt deal poised to deliver big payday to holdouts. February 29

Financial Times (2020b) Argentina clinches near-unanimous backing for debt restructuring, August 31.

Financial Times (2020a) Autonomy hedge fund bemoans Argentina's 'bad faith' debt tactics, June 30.

Flandreau M, Flores J, Gaillard N, Nieto-Parra S (2009) The end of gatekeepers: underwriters and the quality of sovereign bond markets, 1815-2007. NBER Working Paper No. 15128.

Flandreau M (2017) Reputation, regulation and the collapse of international capital markets, 1920-1935, in Financial systems and economic governance: credit crises and regulation from the $19^{\text {th }}$ century to the present, Peter L. Rousseau and Paul Wachtel (eds.). New York: Cambridge University Press.

G-20. (2020) Extraordinary G20 finance ministers and central bank governors' meeting. November 13. http://www.g20.utoronto.ca/2020/2020-g20-finance-1113.html

Gelpern A (2013) Contract hope and sovereign redemption. The Capital Markets Law Journal $8(2): 132-148$ 
Gelpern A (2016) Sovereign debt: now what? The Yale Journal of International Law Online 41(2):45-95

Gelpern A (2018) About government debt... who knows? Capital Markets Law Journal 13(3):321-355

Gelpern A, Gulati M (2013) The wonder clause. Journal of Comparative Law 41:367-385

Gelpern A, Gulati M, Zettlemeyer J (2019) If boilerplate could talk: the work of standard terms in sovereign bond contracts. Law Soc Inq 44(3):617-643

Gelpern A, Horn S, Morris S, Parks B, Trebesch C (2021) How China lends. Center for Global Development, Washington, DC

Gelpern A, Heller B, Setser B (2015) Count the limbs: designing robust aggregation clauses in sovereign bonds. Georgetown Law Faculty Publications and Other Works 1793

Gelpern A, Gulati M, Zettlemeyer J (2018) If boilerplate could talk: the work of standard terms in sovereign bonds. Duke Law School Public Law \& Legal Theory Series No. 2017-45.

Gelpern A (2020) Keeping cozy by the dumpster fire: Argentina reads its contracts ... Twice ... Quel Scandale!, Credit Slips, June 10.

Georgieva K, Pazarbasioglu C, Weeks-Brown R (2020) Reform of the international debt architecture is urgently needed, IMFBlog, October 1.

Gulati M, Weidemaier M (2020) The Argentine re-designation drama: notes from two frustrated readers. Credit Slips, June 9

Guzman M, Stiglitz J (2016) Creating a framework of sovereign debt restructuring that works. In Martin Guzman, José Antonio Ocampo and Joseph Stiglitz (Eds.), Too little, too late: the quest to resolve sovereign debt crises. New York: Columbia University Press.

Hardie I (2006) The power of the markets? The international bond markets and the 2002 elections in Brazil. Review of International Political Economy 13(1):53-77

Hardie I (2011) How much can governments borrow? Financialization and emerging markets government borrowing capacity. Review of International Political Economy 18(2):141-167

Helleiner E (2008) The mystery of the missing sovereign debt restructuring mechanism. Contributions to Political Economy 27(2008):91-113

Horn S, Reinhart C, Trebesch C (2020) China's overseas lending. Manuscript

International Capital Market Association (ICMA) (2014) Standard aggregated collective action clauses for the terms and conditions of sovereign notes. file://Users/giselle/Downloads/ICMA\%20Standard\%20CACs\%20August $\% 202014$.pdf

International Monetary Fund (IMF) (2014) Strengthening the contractual framework to address collective action problems in sovereign debt restructuring. IMF, Washington, DC

International Monetary Fund (IMF) (2019) Fourth progress report on inclusion of enhanced contractual provisions in international bond contracts. IMF, Washington, DC

International Monetary Fund (IMF) (2020) The international architecture for resolving sovereign debt involving private-sector creditors - recent developments, challenges and reform options. IMF, Washington, DC

Kaminsky G, Schmukler S (2003) The center and the periphery: the globalization of financial turmoil, NBER Working Paper No. 9479

Kaplan S, Thomsson K (2014) The political economy o sovereign borrowing: explaining the policy choices of highly indebted poor countries. IIEP Working Paper 2015-1

Karwowski E (2019) Towards (de)finalization: the role of the state. Camb J Econ 43:1001-1027

Karwowski E, Centurion-Vicencio M (2018) Financializing the state: recent developments in fiscal and monetary policy. ffhalshs-01713028f

Kose MA, Nagle P, Ohnsorge F, Sugawara N (2020) Global waves of debt. World Bank, Washington, D.C.

Krueger A (2002) A new approach to sovereign debt restructuring. IMF, Washington, DC

La Nación (2016) El gobierno les pagó US\$9300 millones a los fondos nuitre y dejó atrás el default, April 23 (Buenos Aires)

Lineau O (2014) Rethinking sovereign debt: politics, reputation, and legitimacy in modern finance. Harvard University Press, Cambridge, MA

Livne R, Yonay YP (2016) Performing neoliberal governmentality: an ethnography of financialized sovereign debt management practices. Soc Econ Rev 14(2):339-362

Malpass D (2020) Reversing the inequality pandemic speech delivered at the Frankfurt School of Finance and Management, October 5.

Mosley L (2003) Global capital and national governments. Cambridge University Press, Cambridge, MA

Nevestailova A, Palan R (2020) Sabotage: the business of finance. Allen Lane, London 
Nevestailova A (2012) Money and financialization in the global economy. In Ronen Palan (Ed.), Global political economy: contemporary theories. New York: Routledge

Obstfeld M, Taylor AM (2003) Globalization and capital markets. In Globalization in historical perspective, Michael D. Bordo, Alan M. Taylor and Jeffrey G. Williamsom (eds.). Chicago: University of Chicago Press.

Olivares-Caminal R (2013) Sovereign risk: a world without risk-free assets?, BIS Paper No. 72

Pistor K (2019) The code of capital: how the law creates wealth and inequality. Princeton University Press, Princeton

Pistor K (2013) A legal theory of finance, Columbia Law School Paper No. 13-348

Rethel L (2012) Each time is different! the shifting boundaries of emerging market debt. Glob Soc 26(1):123-143

Sassen S (2001) The Global city: New York, Tokyo, London. Princeton University Press, Princeton

Schwan M, Trampusch C, Fastenrath F (2021) Financialization of, not by the state. Exploring changes in the management of public debt and assets across Europe. Review of International Political Economy 28(4):820-842

Setser B (2008) The political economy of sovereign debt, initiative for policy dialogue working paper series

Sobel M (2016) Strengthening collective action clauses: catalyzing change - the back story. Capital Markets Law Journal 11(1):3-11

Sobel, Mark. 2020. "Argentina and creditors enter new round", OMFIF, June 30.

Strange S (1995) The defective state. Daedalus 124(2):55-74

Tarullo DK (2004) Neither order nor chaos: the legal structure of sovereign debt workouts. Emory Journal of Law 53:657-689

Trampusch C (2019) The financialization of the state: Government debt management reforms in New Zealand and Ireland. Compet Chang 23(1):3-22

United Nations (2014) Resolution on sovereign debt restructuring adopted by general assembly establishes multilateral framework for countries to emerge from financial commitments, GA/11524, September 9.

Verdier P-H (2020) Global banks on trial. Oxford University Press, New York

Wansleben L (2020) Formal institution building in financialized capitalism: the case of repo markets. Theory Soc 49:187-213

Weidemaier WMC, Gelpern A (2013) Injunctions in sovereign debt litigation, UNC Legal Studies Research Paper No. 2330914

Weidemaier WM, Gulati M (2016) Differing perceptions? Market practice and the evolution of foreign sovereign immunity, unpublished manuscript, UNC Chapel Hill and Duke University.

Weidemaier WMC (2014) Sovereign immunity and sovereign debt. Illinois Law Review, 2014(1): $68-114$.

Zettlemeyer J, Trebesch C, Gulati M (2012) The Greek debt exchange: an autopsy. Manuscript 